\title{
GENETIC COLOR POLYMORPHISMS ON COMMON CARP STOCKS IN INDONESIA
}

\author{
Rudhy (Gustiano*)
}

\begin{abstract}
Common carp is the most important species of fish culture in Indonesia, especially in the island of Java. The objective of this study was to clarify the cellular basis of color inheritance among body morphs of this fish. Mendelian test by single pair intra- or inter-color matings of green, yellow and red showed that the $\mathrm{F}_{1}$ generation gave evidence that these phenotypes had the genotypes proposed by previous workers. However, this study proposed other gene symbols for scale type, i.e., $T$ (non-transparent) for wild type and $t$ for transparent. Two loci ( $R_{1}$ and $r_{1}$, $R_{2}$ and $r_{2}$ ) with additive gene effect were probably involved in the production of yellow/red pigment, which were present in the yellow and red morphs. The dominant alleles controlled the amount of pigment produced.
\end{abstract}

KEYWORDS: color inheritance, genetics, common carp.

\section{INTRODUCTION}

Domesticated populations of carp in Indonesia have striking color polymorphisms. Matricia (1990) reported that higher proportion of green common carp were cultured by most farmers in West Java, West and North Sumatera. However, some farmers in West and East Java specialized in producing orange or red colored carps. According to Gustiano \& Phang (1993), specific color selection in each area is influenced by the consumer preference. It is therefore important to elucidate the Mendelian inheritance of color in Indonesian common carp.

Katosonov (1978) working on crosses between Japanese Koi and wild type common carp from the Amur River in Russia showed that the latter was dominant over light colors (orange/yellow and white) of Koi carp. Orange color which was due to a lack of black pigment, is the joint result of 2 recessive alleles $\left(b_{1}\right.$ and $\left.b_{2}\right)$ at 2 independent loci. Genes determining orange color may produce another coloration when combined with other color genes. He suggested that $b_{1}$ and $b_{2}$ genes might, together with the recessive gene (r) of blue color, gave the white color. The genotype of the white Koi might be $b_{1} b_{1} b_{2} b_{2} r r$. He also reported that appearance of black pattern did not appear to be connected with the inheritance of orange and white. The autosomal D and d gene pair was responsible for the presence and absence of the specific pattern on the body of the fish (Katosonov, 1973). Another autosomal gene pair ( $\mathrm{L}$ and $\mathrm{l}$ ) determined dark (common) or light color of the entire body.
Wohlfarth \& Rothbard (1991) and Cherfas et al. (1992) studied the inheritance of the orange colored Koi carp in the Israeli stock and their results fitted the genetic model proposed by Katosonov (1978). A number of color mutants, including gold and gray, had appeared among common carp in Israel (Moav \& Wohlfarth, 1968) and Poland (Wlodek, 1968). All were recessive to the wild type coloration, and were inherited independently.

Based on the above information a study was conducted to confirm the inheritance of the green, yellow and red morphs of common carp cultured in Indonesia.

\section{MATERIALS AND METHODS}

Three uniform color morphs of common carp, green, yellow and red, were used in this study. The green stock, Radjadanu, was obtained from an isolated farm in Kuningan, West Java. The red stock, Cangkringan, was brought from Yogyakarta and the yellow one, Sinyonya, was from Sukabumi, West Java. They were all stocked at the Cijeruk research station, about $10 \mathrm{~km}$ from Bogor, West Java, for spawning.

\section{Single-pair Matings to Produce $F_{1}$ Generation}

Five intra-color single-pair matings were set up for each (green, yellow and red) morphs to produce the $\mathrm{F}_{1}$ progeny, during June 1991-September 1992.

Inter-color single-pair matings were carried out, three pairs for each cross (Table 1). $F_{1}$ offspring

\footnotetext{
*) Researcher of the Research Institute for Freshwater Fisheries, Sukamandi
} 


\section{R. Gustiano}

Table 1. Number of single-pair matings for each intra-color and inter-color mating.

\begin{tabular}{|c|c|c|c|c|}
\hline$\sigma$ & 0 & $\begin{array}{c}\text { Green } \\
\text { ( G ) }\end{array}$ & $\begin{array}{l}\text { Red } \\
\text { ( R ) }\end{array}$ & $\begin{array}{c}\text { Yellow } \\
\text { ( Y ) }\end{array}$ \\
\hline Green & (G) & $5(G \times G)$ & $3(\mathrm{G} X \mathrm{R})$ & $3(\mathrm{G} X \mathrm{X})$ \\
\hline Red & $(\mathrm{R})$ & $3(\mathrm{R} \mathrm{X} \mathrm{G)}$ & 5 (R X R) & $3(\mathrm{R} \mathrm{X} \mathrm{Y})$ \\
\hline Yellow & $(\mathrm{Y})$ & $3(\mathrm{Y} \mathrm{X} \mathrm{G)}$ & $3(\mathrm{Y} \mathrm{X} \mathrm{R})$ & $5(\mathrm{Y} \mathrm{X} \mathrm{Y})$ \\
\hline
\end{tabular}

were scored when their colors developed (10 to 21 days after hatching) using a color standard (on their phenotypes) for textile.

The other data recorded were mating number, parent number (fin clip code), female weight, number of progeny, and color phenotypes. The $\mathrm{F}_{1}$ brood segregation data for color phenotypes for each mating were tested by Chi-square analysis to determine if the observed ratio fit the expected.

\section{Spawning and Fry Rearing}

Natural spawning was carried out in a hapa $\left(2 \times 1 \times 1 \mathrm{~m}^{3}\right.$ size), suspended in a $40 \mathrm{~m}^{2}$ earthen pond. Each spawning used 6 kakabans $\left(1 \times 0.3 \mathrm{~m}^{2}\right)$ which are palm fiber mats, for the attachment of eggs.

These kakabans were kept floating on the water surface in the hapa during spawning. They were inspected regularly and were turned over when the lower side was full of eggs.

Each spawning used equal ratio of body weight of one male to one female. Hatching of the eggs in the hapa occurred after 2 days. After hatching of the eggs, the kakabans were removed and the hapa was sheltered from direct sun light by covering the top with used kakabans. Newly hatched fry remained in the hapa up to 3 days and were then transferred into $40 \mathrm{~m}^{2}$ earthen pond, filled with water, containing chicken manure $\left(1500 \mathrm{~g} / \mathrm{m}^{2}\right)$, of $60 \mathrm{~cm}$ depth. Fry were left to grow in the pond for 10 to 21 days after which they were individually scored for color phenotype. Commercial powdered fish food was given as supplementary food after 10 days of stocking.

\section{RESULTS}

\section{Green X Green Mating}

From 5 matings, all $\mathrm{F}_{1}$ were green colored, like their parents (Table 2). Therefore, all parents were homozygous for green coloration. However, they were segregated into two scale phenotypes. The first was the non-tranparent (wild) green scale and the other was the transparent green color scale.

Microscopic observations showed that the scales of the transparent green phenotype did not have the pigment cell type, iridophores, as light reflecting cells, which were present in the nontranparent green phenotype. Chi-square tests showed that all the observed $F_{1}$ ratios of non-

Table 2. $\quad F_{1}$ offspring of single-pair matings of green $x$ green common carp.

\begin{tabular}{|c|c|c|c|c|c|c|c|c|c|}
\hline \multirow[t]{2}{*}{$\begin{array}{l}\text { Mating } \\
\text { number }\end{array}$} & \multicolumn{2}{|c|}{$\begin{array}{l}\text { Breeder } \\
\text { number }\end{array}$} & \multirow{2}{*}{$\begin{array}{c}\text { Female } \\
\text { w eight } \\
(\mathbf{k g})\end{array}$} & \multirow{2}{*}{$\begin{array}{c}\text { Total } \\
\text { number } \\
\text { of } F_{1}\end{array}$} & \multicolumn{2}{|c|}{$\begin{array}{c}\text { Number of } F_{1} \\
\text { having body color of }\end{array}$} & \multirow[t]{2}{*}{$\begin{array}{l}\text { Expected } \\
\text { ratio }\end{array}$} & \multirow[t]{2}{*}{$\begin{array}{c}\mathrm{X}^{2} \\
(\mathrm{~d} f=1)\end{array}$} & \\
\hline & $\sigma$ & 8 & & & $\begin{array}{c}\text { Non-trans- } \\
\text { parent } \\
\text { green }\end{array}$ & $\begin{array}{c}\text { Trans- } \\
\text { parent } \\
\text { green }\end{array}$ & & & \\
\hline 1 & 1 & 1 & 0.890 & 30 & 27 & 3 & - & - & - \\
\hline 2 & 2 & 2 & 1.150 & 646 & 506 & 140 & $3: 1$ & 3.81 & * \\
\hline 3 & 3 & 3 & 2.490 & 6,844 & 5,132 & 1,712 & $3: 1$ & 0.0004 & * \\
\hline 4 & 4 & 4 & 0.980 & 15,466 & 11,949 & 3,517 & $3: 1$ & 1.76 & ** \\
\hline 5 & 5 & 5 & 1.850 & 5,511 & 4,194 & 1,317 & $3: 1$ & 3.62 & $*$ \\
\hline
\end{tabular}

${ }^{*}=$ not significantly different $(\mathrm{P} \geq 0.05),{ }^{* *}=$ highly significant different $(\mathrm{P}=0.01)$ 
transparent green : transparent green, except mating 4 , fit the expected ratio of $3: 1$. The $F_{1}$ from mating 4 had excess of non-transparent green. These results showed that the green parents were probably heterozygous with the nontransparent wild gene being dominant to the transparent gene.

\section{Yellow X Yellow Mating}

The results of yellow $X$ yellow single-pair matings are shown in Table 3 . The $\mathrm{F}_{1}$ progeny from mating 1 and 2 were all yellow.

The $\mathrm{F}_{1}$ progeny from matings 3,4 and 5 showed yellow or white background (Tables 3 and 4). There were more progenies with yellow color than white. Chi-square tests showed that they deviated significantly from the expected $3: 1$ ratio. Among the progenies of matings 3 and 4 , there was an excess of yellow and deficiency of white phenotype. This deviation from the $3: 1$ ratio may be due to low viability of white progeny. The $\mathrm{F}_{1}$ offspring of mating 5 consisted of about 8 times more yellow than white phenotype. These results showed that the parents were heterozygous for yellow color genes.
$F_{1}$ progenies of 4 matings also showed presence or absence of black color pattern on the background coloration (Table 5). With pattern and without pattern among the $\mathrm{F}_{1}$ from matings 2 and 5 did not fit the expected ratio from (hi-square test. The deviation from the expected ratio in mating 2 was due to an excess of without pattern and deficiency of with pattern phenotype. In contrast, in mating 5 there was more off spring with pattern compared to with expected numbers. In mating 3 and 4 , the ratio between without pattern and with pattern did not fit a $1: 1$ ratio. Deviation from expected numbers was due to an excess of without pattern phenotypes in mating 3 . The reverse was found in mating 4 . Thus the results showed that there was no specific relationship between the with pattern and without pattern phenotypes to survival rate. The gene for pattern was dominant to without pattern. Variation in number of with pattern and without pattern probably was due to the effect of background color (yellow and white) since in this analysis the data was pooled according to presence or absence of pattern. As shown in the previous paragraph, in background analysis, yellow showed better

Table 3. $\quad F_{1}$ offspring of single-pair matings of yellow $\mathrm{X}$ yellow.

\begin{tabular}{|c|c|c|c|c|c|c|c|c|}
\hline \multirow{2}{*}{$\begin{array}{l}\text { Mating } \\
\text { number }\end{array}$} & \multicolumn{2}{|c|}{$\begin{array}{l}\text { Breeder } \\
\text { number }\end{array}$} & \multirow{2}{*}{$\begin{array}{c}\text { Female } \\
\text { w eight } \\
\text { (kg) }\end{array}$} & \multirow{2}{*}{$\begin{array}{c}\text { Total } \\
\text { number } \\
\text { of } \mathrm{F}_{1}\end{array}$} & \multicolumn{4}{|c|}{ Number of $F_{1}$ having body color of } \\
\hline & $\begin{array}{r}\text { nur } \\
\sigma\end{array}$ & $\begin{array}{l}\text { ber } \\
9\end{array}$ & & & Yellow & $\begin{array}{c}\text { Yellow } \\
\text { black }\end{array}$ & White & $\begin{array}{l}\text { White } \\
\text { black }\end{array}$ \\
\hline 1 & 5 & 5 & 3.405 & 22,972 & 22,972 & . & - & . \\
\hline 2 & 2 & 2 & 2.910 & 27,672 & 22,231 & 5,441 & . & . \\
\hline 3 & 1 & 1 & 1.550 & 4,654 & 1,839 & 1,582 & 650 & 583 \\
\hline 4 & 3 & 3 & 1.280 & 1,678 & 555 & 671 & 207 & 245 \\
\hline \multirow[t]{2}{*}{ - } & 4 & 4 & 2.090 & 6,261 & 3,405 & 2,064 & 393 & 399 \\
\hline & & & Total & 63,237 & 51,002 & 9,758 & 1,250 & 1,227 \\
\hline
\end{tabular}

Table 4. $\quad F_{1}$ progeny with yellow background and white background from yellow $\mathrm{X}$ yellow matings.

\begin{tabular}{|c|c|c|c|c|}
\hline \multirow{2}{*}{$\begin{array}{l}\text { Mating } \\
\text { number }\end{array}$} & \multicolumn{2}{|c|}{ Total number of $F_{1}$ with } & \multirow{2}{*}{$\begin{array}{l}\text { Expected } \\
\text { ratio }\end{array}$} & \multirow{2}{*}{$\begin{array}{c}X^{2} \\
(d f=1)\end{array}$} \\
\hline & Yellow & White & & \\
\hline 1 & 22,972 & - & $1: 0$ & - \\
\hline 2 & 27,672 & - & $1: 0$ & - \\
\hline 3 & 3,421 & 1,233 & $3: 1$ & $51.75 * *$ \\
\hline 4 & 1,226 & 452 & $3: 1$ & 16.42 ** \\
\hline 5 & 5,468 & 792 & - & - \\
\hline
\end{tabular}


Table 5. $\quad \mathrm{F}_{1}$ offspring with and without black pattern from yellow $\mathrm{X}$ yellow matings.

\begin{tabular}{ccccc}
\hline $\begin{array}{c}\text { Mating } \\
\text { number }\end{array}$ & \multicolumn{2}{c}{ Total number of $\mathbf{F}_{\mathbf{1}}$ with } & $\begin{array}{c}\text { Expected } \\
\text { ratio }\end{array}$ & $\begin{array}{c}\mathbf{X}^{2} \\
(\mathbf{d f}=\mathbf{1})\end{array}$ \\
\cline { 2 - 4 } 1 & 22,972 & - & $1: 0$ & - \\
2 & 22,231 & 5,441 & $3: 1$ & $420.45 * *$ \\
3 & 2,489 & 2,165 & $1: 1$ & $22.56 * *$ \\
4 & 762 & 916 & $1: 1$ & $14.13 * *$ \\
5 & 3,798 & 2,463 & $3: 1$ & $284.66 * *$ \\
\hline
\end{tabular}

** = highly significantly different $(\mathrm{P} \leq 0.01)$

survival than white background. Another reason could be that the pattern is a multigenic trait. Thus the observed segregation data did not fit the expected ratios based on single gene inheritance.

\section{Red X Red Mating}

Four matings of red $\mathrm{X}$ red gave all $\mathrm{F}_{1}$ progeny with red background (Table 6) showing that the parents were homozygous for red color.

However, the $F_{1}$ progeny from mating 2 segregated into 2 phenotypes, 2,087 red 660 red with greenish band along the dorsal region. The latter is referred to as the greenish red color phenotype. The Chi-square test showed that the ratio of red to greenish red offspring from this mating fit the expected $3: 1$ ratio. This gave evidence that both parents of mating 2 were heterozygous with the gene causing the greenish band being recessive to the no banding allele.

\section{Green X Yellow Cross}

All three single-pair matings of this cross gave only green $F_{1}$ progeny showing that green color was epistatic to yellow (Table 7). The yellow phenotype was the result of combination of two recessive genes, $b_{1}$ and $b_{2}$ (Katosonov, 1978). Thus, the green female parent contributed the dominant $\mathrm{B}_{1}$ or $\mathrm{B}_{2}$ gene that controlled black pigmentation.

However, the reciprocal cross of yellow female $\mathrm{X}$ green male gave one quarter yellow and three quarters green progenies (Table 8). There was no significant difference from the expected ratio of 3 green : 1 yellow, except in mating 3 where there was an excess of green and deficiency of yellow. These results showed that green male parents were most probably heterozygous for green color and yellow females homozygous for yellow color. This study proposed that the green genotype was $B_{1} b_{1} B_{2} b_{2} R_{-}$and yellow was $b_{1} b_{1} b_{2} b_{2} R R$ following the model proposed by Katosonov (1978).

\section{Green X Red Cross}

This crossing gave similar result to those of the green with yellow cross. All $F_{1}$ progeny from red male $\mathrm{X}$ green female crosses were green showing that green color was epistatic to red (Table 9). The mechanism of epistasis was

Table 6. $\quad \mathrm{F}_{1}$ offspring of red $\mathrm{X}$ red matings.

\begin{tabular}{|c|c|c|c|c|c|c|c|c|}
\hline \multirow[t]{3}{*}{$\begin{array}{l}\text { Mating } \\
\text { number }\end{array}$} & \multirow{2}{*}{\multicolumn{2}{|c|}{$\begin{array}{l}\text { Breeder } \\
\text { number }\end{array}$}} & \multirow{3}{*}{$\begin{array}{c}\text { Female } \\
\text { weight } \\
\text { (kg) }\end{array}$} & \multirow{3}{*}{$\begin{array}{c}\text { Total } \\
\text { number } \\
\text { of } F_{1}\end{array}$} & \multicolumn{2}{|c|}{$\begin{array}{c}\text { Number of } F_{1} \text { having } \\
\text { body color of }\end{array}$} & \multirow[t]{3}{*}{$\begin{array}{l}\text { Expected } \\
\text { ratio }\end{array}$} & \multirow[t]{3}{*}{$x^{2}$} \\
\hline & & & & & \multirow{2}{*}{ Red } & \multirow{2}{*}{$\begin{array}{l}\text { Greenish } \\
\text { red }\end{array}$} & & \\
\hline & $\sigma$ & 9 & & & & & & \\
\hline 1 & 1 & 1 & 0.660 & 322 & 317 & - & $1: 0$ & - \\
\hline 2 & 2 & 2 & 0.870 & 2,747 & 2,087 & 660 & $3: 1$ & $3.39^{*}$ \\
\hline 3 & 3 & 3 & 0.870 & 1,742 & 1,742 & - & $1: 0$ & \\
\hline 4 & 4 & 4 & 0.960 & 3,926 & 3,926 & - & $1: 0$ & \\
\hline 5 & 5 & 5 & 0.950 & 4,955 & 4,967 & - & $1: 0$ & \\
\hline
\end{tabular}

* = not significantly different $(\mathrm{P} \geq 0.05)$ 
Table 7. $\quad F_{1}$ offspring of single pair crossing of yellow male $\mathrm{X}$ green female.

\begin{tabular}{|c|c|c|c|c|c|c|}
\hline \multirow[t]{2}{*}{$\begin{array}{l}\text { Crossing } \\
\text { number }\end{array}$} & \multicolumn{2}{|c|}{$\begin{array}{l}\text { Breeder } \\
\text { number }\end{array}$} & \multirow{2}{*}{$\begin{array}{c}\text { Female } \\
\text { weight } \\
\text { (kg) }\end{array}$} & \multirow{2}{*}{$\begin{array}{c}\text { Total } \\
\text { number } \\
\text { of } F_{1}\end{array}$} & \multicolumn{2}{|c|}{$\begin{array}{c}\text { Number of } F_{1} \text { having } \\
\text { body color of }\end{array}$} \\
\hline & $\alpha$ & 오 & & & Green & Yellow \\
\hline 1 & 1 & 5 & 0.980 & 5,086 & 5,086 & - \\
\hline 2 & 1 & 4 & 2.380 & 33,102 & 33,102 & . \\
\hline 3 & 1 & 2 & 3.330 & 23,889 & 23,889 & . \\
\hline
\end{tabular}

Table 8. F1 offspring of green male X yellow female.

\begin{tabular}{|c|c|c|c|c|c|c|c|c|}
\hline \multirow[t]{2}{*}{$\begin{array}{l}\text { Mating } \\
\text { number }\end{array}$} & \multicolumn{2}{|c|}{$\begin{array}{l}\text { Breeder } \\
\text { number }\end{array}$} & \multirow{2}{*}{$\begin{array}{c}\text { Female } \\
\text { weight } \\
\text { (kg) }\end{array}$} & \multirow{2}{*}{$\begin{array}{c}\text { Total } \\
\text { number } \\
\text { of } \mathrm{F}_{1}\end{array}$} & \multicolumn{2}{|c|}{$\begin{array}{c}\text { Number of } F_{1} \text { having } \\
\text { body color of }\end{array}$} & \multirow[t]{2}{*}{$\begin{array}{l}\text { Expected } \\
\text { ratio }\end{array}$} & \multirow[t]{2}{*}{$\mathrm{X}^{2}$} \\
\hline & $\sigma$ & 9 & & & Green & Yellow & & \\
\hline 1 & 3 & 2 & 4.050 & 11,419 & 8,650 & 2,769 & $3: 1$ & 3.43 \\
\hline 2 & 2 & 4 & 1.820 & 36 & 29 & 7 & $3: 1$ & 0.59 \\
\hline 3 & 5 & 3 & 3.800 & 28,132 & 21,415 & 6,717 & $3: 1$ & $4.68^{* * *}$ \\
\hline
\end{tabular}

Table 9. $\quad \mathrm{F}_{1}$ offspring of red male X green femele croosses.

\begin{tabular}{|c|c|c|c|c|c|c|}
\hline \multirow[t]{2}{*}{$\begin{array}{l}\text { Mating } \\
\text { number }\end{array}$} & \multicolumn{2}{|c|}{$\begin{array}{l}\text { Breeder } \\
\text { number }\end{array}$} & \multirow{2}{*}{$\begin{array}{c}\text { Female } \\
\text { weight } \\
\text { (kg) }\end{array}$} & \multirow{2}{*}{$\begin{array}{c}\text { Total } \\
\text { number } \\
\text { of } F_{1}\end{array}$} & \multicolumn{2}{|c|}{$\begin{array}{c}\text { Number of } F_{1} \text { having } \\
\text { body color of }\end{array}$} \\
\hline & $\sigma$ & 9 & & & Green & Red \\
\hline 1 & 1 & 4 & 2.160 & 3,562 & 3,562 & . \\
\hline 2 & 6 & 5 & 2.740 & 14,500 & 14,498 & . \\
\hline 3 & 4 & 2 & 3. 170 & 53,026 & 53,026 & - \\
\hline
\end{tabular}

Table 10. $\quad F_{1}$ offspring of green male $\mathrm{X}$ red female.

\begin{tabular}{|c|c|c|c|c|c|c|c|c|}
\hline \multirow[t]{2}{*}{$\begin{array}{l}\text { Mating } \\
\text { number }\end{array}$} & \multicolumn{2}{|c|}{$\begin{array}{l}\text { Breeder } \\
\text { number }\end{array}$} & \multirow{2}{*}{$\begin{array}{c}\text { Female } \\
\text { weight } \\
\text { (kg) }\end{array}$} & \multirow{2}{*}{$\begin{array}{c}\text { Total } \\
\text { number } \\
\text { of } F_{1}\end{array}$} & \multicolumn{2}{|c|}{$\begin{array}{l}\text { Number of } F_{1} \text { having } \\
\text { body color of }\end{array}$} & \multirow[t]{2}{*}{$\begin{array}{l}\text { Expected } \\
\text { ratio }\end{array}$} & \multirow[t]{2}{*}{$\mathrm{X}^{2}$} \\
\hline & $\sigma$ & 9 & & & Green & Red & & \\
\hline 1 & 3 & 5 & 0.920 & 3,701 & 2,827 & 874 & $3: 1$ & $3.78^{*}$ \\
\hline 2 & 5 & 6 & 1.210 & 9,428 & 7,211 & 2,217 & $3: 1$ & 2.71 * \\
\hline 3 & 6 & 3 & 1.550 & 6,699 & 4,992 & 1,707 & $3: 1$ & $0.64^{*}$ \\
\hline
\end{tabular}

* = not significantly different $(P \geq 0.05)$ 


\section{R. Gustiano}

probably similar to the crosses between yellow male and green female.

In the reciprocal cross using red female as spawner, the $\mathrm{F}_{1}$ progeny consisted of one quarter red and three quarters green. All Chi-square tests showed no significant differences at $\mathrm{P}=0.05$ (Table 10). The results were similar to those of the cross between yellow female and green male. Thus, these results supported the possibility of heterozygosity of all green male parents used in this cross.

\section{Red X Yellow Cross}

All $\mathrm{F}_{1}$ progeny from the cross of red male with yellow female had red color backround (Table 11) with exception of mating 2 which also had 29 yellow progeny. The red color was most probably controlled by more than one gene locus with

\section{DISCUSSION}

Mating of green $\mathrm{X}$ green showed that all the parents were homozygous for the green color. However, they were heterozygous for the scale type since the $F_{1}$ progeny showed approximately $3: 1$ ratio between non-transparent (wild) and tranparent scale type (Table 2). The green male and female parents used in these matings were probably heterozygous for scale type, with the nontransparent being dominant over the transparent scale type. Previous workers on common carp also reported that the wild phenotype is dominant over other mutant phenotypes (Katosonov, 1978; (Cherfas et al. 1990). The proposed gene symbols for the scale type is $\mathrm{T}$ (non-transparent) for the wild-type and $t$ for transparent. Both parents of the green $\mathrm{X}$ green matings must be Tt heterozygotes.

Table 11. $\mathrm{F}_{1}$ offspring of red male $\mathrm{X}$ yellow female.

\begin{tabular}{|c|c|c|c|c|c|c|}
\hline \multirow[t]{2}{*}{$\begin{array}{l}\text { Mating } \\
\text { number }\end{array}$} & \multicolumn{2}{|c|}{$\begin{array}{l}\text { Breeder } \\
\text { number }\end{array}$} & \multirow{2}{*}{$\begin{array}{c}\text { Female } \\
\text { weight } \\
\text { (kg) }\end{array}$} & \multirow{2}{*}{$\begin{array}{c}\text { Total } \\
\text { number } \\
\text { of } F_{1}\end{array}$} & \multicolumn{2}{|c|}{$\begin{array}{c}\text { Number of } F_{1} \text { having } \\
\text { body color of }\end{array}$} \\
\hline & $\sigma$ & 9 & & & Red & Yellow \\
\hline 1 & 5 & 2 & 4.620 & 2,380 & 2,380 & $\cdot$ \\
\hline 2 & 3 & 4 & 2.000 & 3,865 & 3,836 & 29 \\
\hline 3 & 3 & 5 & 3.550 & 6,644 & 6,644 & - \\
\hline
\end{tabular}

additive gene effects which were involved in the production of yellow/red pigment.

The reciprocal cross using green male with red female gave F1 progeny with red color background (Table 12). The results showed that most of red parents used in these crossings were homozygous dominant.
Genetic studies on goldfish showed that the character of transparent scale was controlled by a single autosomal gene (Kajishima, 1977). The dominant allele (g) controlled guanine synthesis in the iridophores while the recessive allele $(\mathrm{g})$ lacked this potency thus causing scales to be transparent. Similarly, Moore (1974) working on

Table $12, \mathrm{~F}_{1}$ offspring of yellow male $\mathrm{X}$ red female.

\begin{tabular}{|c|c|c|c|c|c|c|}
\hline \multirow[t]{2}{*}{$\begin{array}{l}\text { Mating } \\
\text { number }\end{array}$} & \multicolumn{2}{|c|}{$\begin{array}{l}\text { Breeder } \\
\text { number }\end{array}$} & \multirow{2}{*}{$\begin{array}{c}\text { Female } \\
\text { weight } \\
\text { (kg) }\end{array}$} & \multirow{2}{*}{$\begin{array}{c}\text { Total } \\
\text { number } \\
\text { of } F_{1}\end{array}$} & \multicolumn{2}{|c|}{$\begin{array}{c}\text { Number of } F_{1} \\
\text { having body color of }\end{array}$} \\
\hline & $\sigma$ & 9 & & & Red & Yellow \\
\hline 1 & 1 & 5 & 1.250 & 4,013 & 4,013 & - \\
\hline 2 & 3 & 3 & 1.730 & 2,594 & 2,594 & $\cdot$ \\
\hline 3 & 2 & 3 & 1.900 & 21,095 & 21,095 & - \\
\hline
\end{tabular}


Poeciliopsis lucida Miller, reported that the transparent allele (tr) which caused absence of iridophores was inherited as a simple autosomal recessive allele. It was likely that the transparent gene acts to terminate proliferation of iridophores. The scales of transparent green $F_{1}$ progeny found in this study were completely devoid of iridophores.

The $\mathrm{F}_{1}$ offspring from yellow $\mathrm{X}$ yellow matings could be classified into two groups based on their color backgrounds, yellow and white. All of the white progeny had black and yellowish pigmentation, in the iris of the eye. Study of albinistic common carp from Roosevelt lake, Arizona, by Johnson (1968) reported that none of them were true albinos, since all had dark, wine-red eyes. The present data showed that ratio between yellow and white was close to $3: 1$, except in matings 1, 2 and 5 (Table 4). However, Chi-square tests showed that the observed ratio was significantly different from the expected. The proposed genotype for yellow parents for matings 1 and 2 was homozygous dominant, RR and heterozygous $\mathrm{Rr}$ for parents of the other three matings.

Deviation from the expected ratio in mating 3 and 4 was due to an excess of yellow and deficiency of white phenotypes. Lower fitness of the white colored morph might be the cause of the observed deviation from the expected. Similar observations were reported by Wohlfarth \& Rothbard (1991). Katosonov (1978) and Cherfas et al. (1992) concluded that genes for white coloration in common carp were the most recessive among the color phenotypes. They reported that genes for white coloration, were $b_{1} b_{1} b_{2} b_{2}$ rr. A similar genotype was also suggested by Yamamoto (1973) for albino goldfish.

Katosonov (1976) reported that the light color genes in carp manifested lethal effects when homozygous, with mortality occurred during the post embryonic period, mainly at the fingerling stage of development. Bondari (1984) reported that albino fry channel catfish were also less viable than normal ones. According to Bridge and Limbach (1972), the rareness of the occurrence of albinos in natural rainbow trout populations was because that they were not well suited for natural stream or lake environments.

$F_{1}$ from yellow $X$ yellow matings were classified and analyzed separately for background color and black color pattern. Wohlfarth \& Rothbard (1991) also reported that the appearance of colored pattern did not appear to be connected with the inheritance of color background. According to Katosonov (1973), background color and color pattern were due to the presence of two unlinked, clearly autosomal gene pairs. This study proposed that without pattern genotype was controlled by the dominant gene $(\mathrm{P})$ and with pattern by the recessive allele $(p)$. This proposed genotype was probably similar to the gene $\mathrm{D}$, which controlled pattern on common carp as proposed by Katosonov (1978). The $F_{1}$ results of presence or absence of pattern from yellow $\mathrm{X}$ yellow matings showed 2 kinds of ratios. The first was $3: 1$ showing that both the parents were heterozygous for gene pattern, pp. The second was $1: 1$ (Table 5) which meant that in that particullar case one of the parents was homozygous recessive for pattern $(\mathrm{Pp})$. However, that homozygous recessive parent for pattern was undetectable at spawning time. This could be possible because all the spawners were kept in a concrete tank for a long time before the crossing experiment. In some fishes, the color pattern, may disappear or becomes blurred during the long period of storage in concrete tanks where they were fed with commercial pellets.

In the red $\mathrm{X}$ red matings, all the parents were homozygous for red background color, since all the progeny were red colored. However, mating 2 produced some greenish red progeny and the obseved ratio confirmed to $3: 1$ ratio between red and greenish red (Table 6). This shows that the red parents of this mating must be heterozygous, with the greenish band gene being recessive. However, it was difficult to propose a gene model responsible for the band based on results from one mating.

Green $\mathrm{X}$ yellow and green $\mathrm{X}$ red crosses gave similar results. When green females were used in the crossing, all the progeny were green (Table 7 and 9). The proposals of green backgound color (wild-type) being epistatic to light colors (yellow and red) are reported by previous workers on common carp (Katosonov, 1978; Taniguchi et al., 1986; (Cherfas et al., 1990).

However when green colored male was used to cross with yellow or red females, the progeny produced were approximately one quarter yellow or red color, respectively (Tables 8 and 10). These results showed that green parents were most probably heterozygous $\left(\mathrm{B}_{1} \mathrm{~b}_{1} \mathrm{~B}_{2} \mathrm{~b}_{2} \mathrm{Rr}\right)$ while the yellow and red female were homozygous dominant ( $\left.b_{1} b_{1} b_{2} b_{2} R R\right)$.

Crossing between yellow and red produced $F_{1}$ progeny with red background (Table 11 and 12) indicating that red was dominant over yellow 


\section{R. Gustiano}

coloration. Chemical analysis of the pigment cells (Gustiano, 1995) showed that red and yellow morphs had similar pigment contents. However, they differred in the density of carotenoids in their chromatophores. Red and yellow color were probably polygenic characters Each genetic combination produced a variation in the carotenoid content. Previous workers (Katosonov, 1978; Wohlfarth \& Rothbard, 1991; Cherfas et al., 1992), working on orange and yellow color of Koi carp, did not analyze them separately, but pooled them into one group. It was therefore difficult to confirm the results of the red $\mathrm{X}$ yellow cross. We proposed that two loci $\left(R_{1}\right.$ and $r_{1}, R_{2}$ and $\left.r_{2}\right)$ were probably involved to form yellow and red phenotypes. In contrast to Katasonov (1978) who proposed a single gene locus ( $R$ and $r$ ), our data gave indication that more than 1 locus were involved in the production of yellow and red pigments. These 2 dominant genes controlled the amount of pigments produced. Thus red phenotype might have genotypes

$b_{1} b_{1} b_{2} b_{2} R_{1} R_{1} R_{2} R_{2}, \quad b_{1} b_{1} b_{2} b_{2} R_{1} R_{1} R_{2} r_{2}$ or $b_{1} b_{1} b_{2} b_{2} R_{1} r_{1} R_{2} R_{2}$ and yellow are

$b_{1} b_{1} b_{2} b_{2} R_{1} R_{1} r_{2} r_{2}, \quad b_{1} b_{1} b_{2} b_{2} r_{1} r_{1} R_{2} R_{2}$,

$b_{1} b_{1} b_{2} b_{2} R_{1} r_{1} R_{2} r_{2}, \quad b_{1} b_{1} b_{2} b_{2} R_{1} r_{1} r_{2} r_{2}$ or

$b_{2} b_{1} b_{2} b_{2} r_{1} r_{1} R_{2} r_{2}$.

The other source of the intensity differences on red and yellow was probably due to environmental effect like diet, sunlight and water quality.

Proposed genotype (s) the various color phenotype (s) of common carp are:

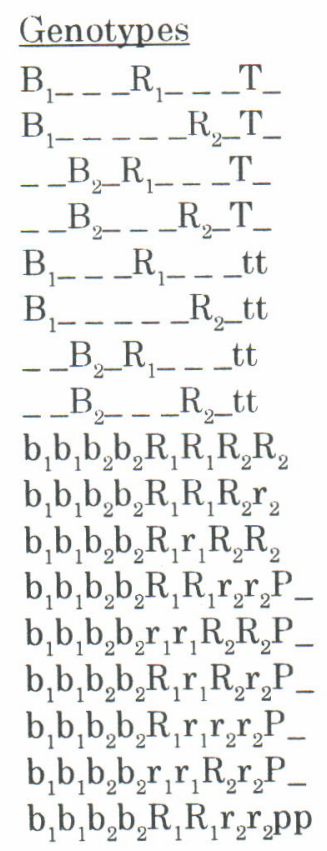

Phenotypes

wild green

transparent green

red color background

yellow color background

yellow color back ground

with black pattern $b_{1} b_{1} b_{2} b_{2} r_{1} r_{1} R_{2} R_{2} p p$

$b_{1} b_{1} b_{2} b_{2} R_{1} r_{1} R_{2} r_{2} p p$

$b_{1} b_{1} b_{2} b_{2} R_{1} r_{1} r_{2} r_{2} p p$

$b_{1} b_{1} b_{2} b_{2} r_{1} r_{1} R_{2} r_{2} p p$

$b_{1} b_{1} b_{2} b_{2} r_{1} r_{1} r_{2} r_{2} P_{-}$

$b_{1} b_{1} b_{2} b_{2} r_{1} r_{1} r_{2} r_{2} p p$

$B_{1---} r_{1} r_{1} r_{2} r_{2} P P$

$-B_{2}-r_{1} r_{1} r_{2} r_{2} P P$

white color background

white color

background with black

pattern

blue color background

\section{CONCLUSION}

Various color phenotypes of common carp cultured in Indonesia were mainly controlled by simple mendelian inheritance. Symbols for gene loci in common carp proposed are as follows : $B_{1}$ and $\mathrm{B}_{2}$ for common green body background (wild type allele), $R_{1}$ and $R_{2}$ for red or yellow, $T$ for wild non-transparent scale type and $P$ for uniform body color background. $B_{1}$ and $B_{2}$ are epistatic to the $\mathrm{R}_{1}$ and $\mathrm{R}_{2}$ genes.

\section{ACKNOWLEDGEMENT}

This work was supported by IDRC Canada from the Aquaculture Genetics Project 3 - p - 88 - 0334. Sincere thanks are due to Prof. R.W. Doyle for his encouragement to this study and Prof. V.P.E. Phang for her advice and guidance in the study and to all colleageus for their supports.

\section{REFERENCES}

Bondari, K. 1984. Comparative performance of albino and normally pigmented channel catfish in tanks, cages, and ponds. Aquaculture 37: 293-301.

Bridge, W.R. and Limbach, B.V. 1972. Inheritance of albinism in rainbow trout. J. Hered. 63: 152-153.

Cherfas, N.B., Kozinsky, (.), Rothbard, S. and Hulata, (x. 1990. Induced diploid gynogenesis and triploidy in ornamental (Koi) carp. Isr. J. Aquacult. Bamidgeh 42: 3-9.

Cherfas, N.B., Peretz, Y. and Ben-dom, N. 1992. Inheritance of the orange type pigmentation in Japanese carp (Koi) in the Israeli stock. Isr. J. Aquacult. Bamidgeh 44: 32-34.

Gustiano, R. and Phang, V.P.E. 1993. The occurrence of color polymorphisms in common carp cultured in Indonesia. BIOTROP Spec. Publ. 51: 25-30.

Gustiano, R. 1995. Chemical analysis of pigment cells in common carp. Terubuk 60: 96-101.

Johnson, J.E. 1968. Albinistic carp, Cyprinus carpio, from Roosevelt Lake, rizone. Trans. Am. Fish. Soc. 97: 209-211. 
Kajishima, T. 1977. Genetics and development analysis of some new color mutants in gold fish, Carassius auratus. Genetics 86: 161-174.

Katosonov, V.Ya. 1973. Investigation of color in hybrids of common and ornamental (Japanese) carp. I: Transmission of dominant color type. Genetika (Moscow) 9: 59-69.

Katosonov, V.Ya. 1976. Lethal action of the light color gene in carp (Cyprinus carpio L.). Genetika (Moscow) 12: 152-155.

Katosonov, V.Ya. 1978. Color in hybrids of common and ornamental (Japanese) carps. III: Inheritance of blue and orange color types. Genetika (Moskow) 14: 2184-2192.

Matricia, T. 1990. Morphological and Growth Variability among Common Carp Population in Different Geographical Areas in Indonesia. M.Sc. Thesis. Dalhousie Univ., Halifax, NS, Canada. 170 pp.

Moav, R. and Wohlfarth, G.W. 1968. Genetic improvement of yield in carp. Proc. of the World Symp. on
Warm Water Pond Fish Culture. FAO. Fish. Rep. 44: $12-29$.

Moore, W.S. 1974. A mutant affecting chromatophore proliferation in a poeciliid fish. J. Hered. 65: 326330.

Taniguchi, N., Kajima, A., Tamura, T., Takegami, K. and Yamazaki, I. 1986. Color, growth and maturation in ploidy manipulated fancy carp. Aquaculture 57: 321-328.

Wohlfarth, G.W. and Rothbard, S. 1991. Preliminary investigation on color inheritance in Japanese ornamental carp. (Nishigi-(.oi). Isr. J. Aquaculture Bamidgeh 43(2): 62-68.

Wlodek, J.M. 1968. Studies on the breeding of carp (Cyprinus carpio) at the experimental pond farm of the Polish Academy of Sciences in Southern Silesia, Poland. Proc. of the World Symp. on Warm Water Pond Fish Culture. FAO. Fish. Rep. 44: 93116.

Yamamoto, T.O. 1973. Inheritance of albinism in the goldfish, Carassius auratus. Jap. J. Genet. 48: 5364. 